\title{
Arbor
}

\section{Retrovirus endógenos humanos: Significado biológico e implicaciones evolutivas}

\author{
Carlos Sentís
}

Arbor CLXXII, 677 (Mayo), 135-166 pp.

El genoma humano contiene un importante número de retrovirus endógenos (HERVs), es decir, secuencias derivadas de pasadas infecciones retrovirales insertadas de forma permanente; $y$ secuencias similares se pueden observar en prácticamente todos los organismos eucariontes. Muchos de estos HERVs se transcriben y traducen en condiciones fisiológicas normales, llegando a formar partículas virales completas, y participando en procesos tan complejos como la placentación. Por su capacidad de retrotransposición y recombinación entre ellos son una fuente importante de remodelación genómica $y$, junto con otros retroelementos, participan en la generación de retrogenes y retropseudogenes, que suponen un sustrato de variabilidad informacional fundamental para la aparición de nuevas estructuras y funciones. Puesto que su actividad responde también a las condiciones ambientales, los cambios genómicos generados por ellos no son graduales, sino que aparecen en oleadas, de modo que se puede producir una variedad fenotípica muy extensa en momentos evolutivos concretos, coincidiendo con situaciones ambientales críticas. La consideración de los HERVs como parte integral y consustancial de nuestro genoma obliga a replantearse la utilización de vectores retrovirales en protocolos de terapia génica, así como la utilización de órganos animales -con sus propios retrovirus endógenos-para xenotrasplantes.

Cerca del 10\% del Genoma Humano está compuesto por secuencias de origen retroviral muy diferentes entre sí pero englobadas bajo la deno- 
minación genérica de retrovirus endógenos humanos o HERVs (de sus siglas en inglés). La estructura de los HERVs es la característica de los retrovirus exógenos (RVs) en su forma de provirus, con dos repeticiones terminales largas en los extremos (LTRs) y los genes gag, pol y env, que codifican las proteínas necesarias para la formación de nuevas partículas virales, incluyendo la Transcriptasa Inversa (RT) que permite la transcripción de un molde de RNA en DNA (retrotranscripción), y es, por tanto, parte esencial del ciclo vital de los retrovirus. Las LTRs se generan durante el proceso de retrotranscripción y son necesarias para la integración viral en el DNA genómico (Figura 1). Además, presentan los elementos necesarios para regular la expresión de sus genes, incluyendo las secuencias de unión a factores de transcripción y hormonas, y las señales de poliadenilación para el correcto procesamiento de los RNAs virales. Al formar parte del genoma, los HERVs se transmiten de modo vertical (mendeliano) a la descendencia, mientras que los RVs se transmiten de modo horizontal (infectivo) entre los individuos de una población, afectando a tipos celulares concretos, normalmente células somáticas. Durante el curso de la evolución los progenitores exógenos de los HERVs tuvieron que insertarse en las células de la línea germinal, convirtiéndose en endógenos (Löwer et al., 1996). Aunque las infecciones de la línea germinal no deben ser un evento muy frecuente, ha debido haber varios sucesos de este tipo ya que existen diversas familias de HERVs poco relacionadas entre sí y cada una de ellas presenta secuencias homólogas en otros grupos animales, sobre todo en Primates (Bock y Stoye, 2000; Weiss, 2000). Una vez integrados, los -ahora- HERVs han sufrido múltiples eventos de retrotransposición (amplificación y transposición), gracias a la presencia de las LTRs y del gen de la RT, de modo que se han ido generando miles de secuencias retrovirales, parciales o completas, que se encuentran dispersas por el genoma. Algunas de estas secuencias mantienen la estructura proviral completa y son capaces de formar partículas virales, mientras que muchas de ellas son defectivas y han perdido la capacidad individual de replicarse, y la inmensa mayoría son LTRs solitarias, habiendo perdido todos los genes estructurales, pero manteniendo su capacidad reguladora. En cualquier caso, defectivas o no, estas secuencias pueden tener o retener funciones biológicas diversas, aunque el posible significado biológico y evolutivo de las secuencias retrovirales humanas sigue siendo bastante polémico, pese a que su potencial en ambos sentidos es enorme: son secuencias complejas, con capacidad de regulación y procesamiento espacio-temporal, con lo que sus productos estructurales (los productos de sus genes) pueden tener funciones diferentes, dependiendo del entorno celular y del momento de desarrollo en 
Retrovirus endógenos humanos: Significado biológico...
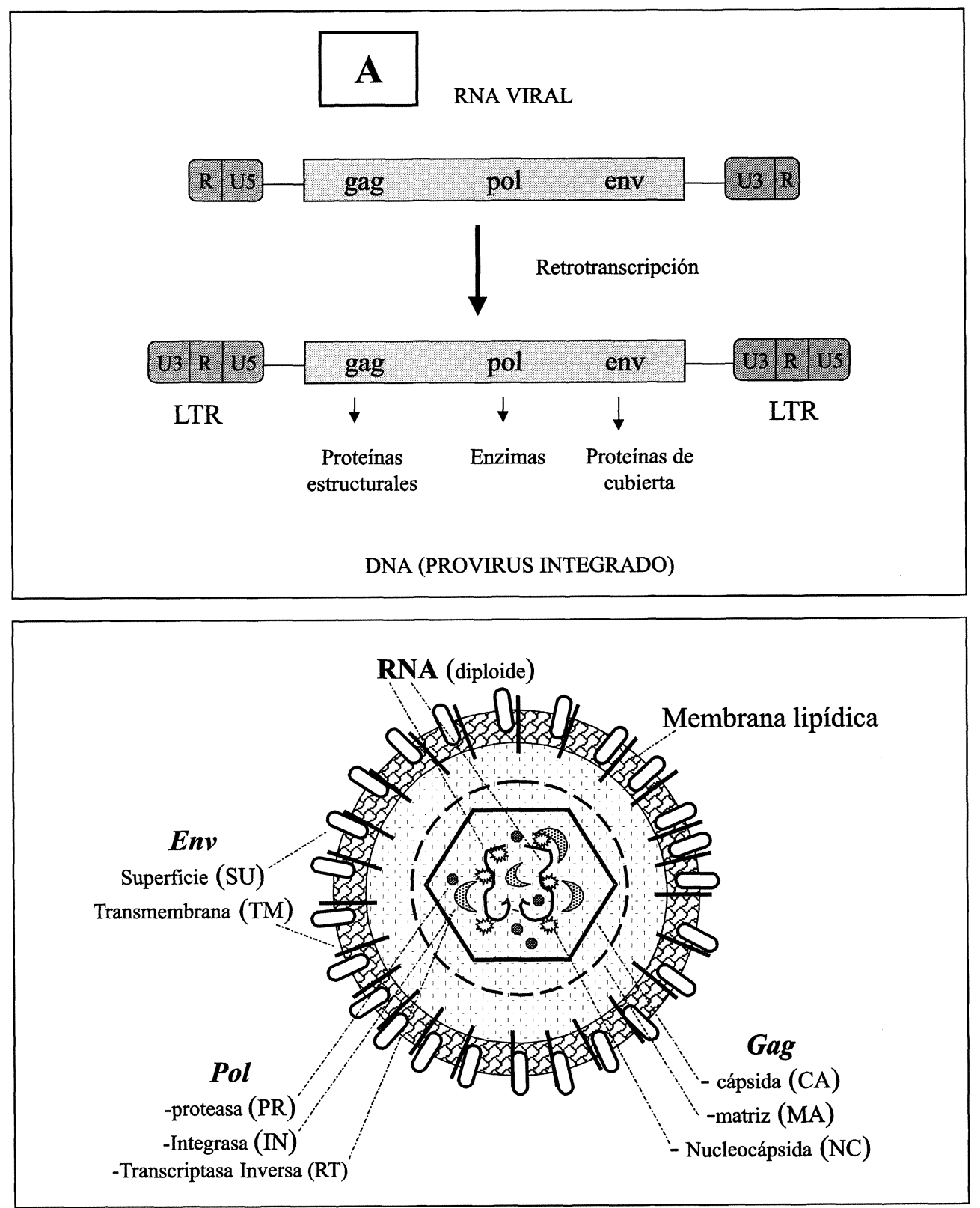

Figura 1. A) Organización genómica simplificada de un retrovirus en su forma libre, como RNA o integrada en el genoma como provirus. Esta última estructura y sus variantes defectivas es la que corresponde a los HERVs . B) Sección transversal esquemática de una partícula retroviral con sus distintos componentes producidos todos ellos por los genes virales en su estadio de provirus. La capa lipídica se adquiere durante la salida del virus de la célula huésped 
el que se expresen. Además, sus secuencias reguladoras (las LTRs) pueden afectar a la regulación de genes cercanos, dotándoles de características funcionales específicas y durante el proceso de retrotransposición se pueden generar nuevas especificidades y funciones, así como transducir otros genes, ubicándolos en nuevos entornos genómicos con (o sin) nuevas funciones. En su forma de partículas los retrovirus son diploides, ya que encapsulan dos moléculas de RNA, y como consecuencia, tienen una alta tasa de recombinación intra e intermolecular, lo que genera nuevas moléculas de RNA y permite la incorporación de una información genética distinta de la de los RNAs parentales en las células infectadas (Mikkelsen y Pedersen, 2000; Zhang y Ma., 2001).

También se está demostrando recientemente la implicación de los HERVs en funciones celulares normales, e incluso se les ha implicado en procesos tan complejos e importantes evolutivamente como la placentación. Sin embargo, desde su descubrimiento en 1981 (Martin et al., 1981) los HERVs comenzaron por considerarse exclusivamente como potenciales agentes patogénicos sobre todo en procesos cancerosos y autoinmunes, y esta postura ha sido recientemente reforzada por algunos autores (Löwer, 1999). Aunque es perfectamente posible la implicación de los HERVs en diversas enfermedades -incluyendo recientemente la esquizofrenia (Karlsson et al., 2001)-, centrar su potencial papel biológico en su patogenicidad resulta simplista y contrario a las evidencias experimentales. A principios de la década de los 80 esta postura era comprensible, ya que lo que se conocía de retrovirus animales era su capacidad oncogénica y, con la aparición del SIDA y la posterior asociación entre esta enfermedad y el retrovirus HIV, sólo se podían imaginar como agentes infectivos patógenos, pero la realidad es que la mayoría de los retrovirus infectivos (exógenos) humanos tiene un potencial patogénico bajo (caso del HTLV-1) o nulo (como el HTLV-2 y el Espumavirus humano o HFV), excepto en conjunción con otras infecciones virales, especialmente con Herpesvirus (Israel et al., 1995). En el caso de los retrovirus endógenos no se ha podido demostrar su papel causal en ninguna enfermedad, aunque, como secuencias genómicas que son, probablemente, en algunos casos, las mutaciones y los fallos de regulación de su expresión tengan consecuencias patológicas como sucede con cualquier otro gen.

Más allá de su posible implicación en enfermedades, se pueden apreciar generalmente dos enfoques diferentes a la hora de analizar el papel de los HERVs y sus consecuencias evolutivas que se centran en la cuestión sobre si son parásitos o simbiontes. El primer punto de vista considera que, puesto que son el resultado de una infección retroviral de la línea germinal, estas secuencias son parásitos infiltrados en nuestro 
Retrovirus endógenos humanos: Significado biológico...

genoma, que utilizan la maquinaria celular en su beneficio. Por tanto, los HERVs (y dentro de esta perspectiva se incluiría el resto de los elementos móviles, lo que supone hasta el 50\% del genoma humano) serían DNA egoísta, también llamado DNA basura, y están en permanente competencia con las secuencias celulares residentes, sin aportar nada al anfitrión, excepto los problemas derivados de su propia retrotransposición, que puede ser una fuente de mutaciones, principalmente mediante mutagénesis insercional. Como expresaron acertadamente Zuckerkandl y Hennig (1995): «Dada la suficiente falta de comprensión, cualquier cosa (y esto incluye un cuarteto de Mozart) puede ser declarada basura» (el resaltado es de los autores). El segundo punto de vista las considera secuencias simbiontes (o mutualistas), es decir, les adjudican ciertas funciones beneficiosas para la célula que se han adquirido muy posteriormente a la infección (genes exaptados, según la terminología de Brosius y Gould, (1992)). Sin embargo, las evidencias más recientes muestran cada vez más la implicación de los HERVs en procesos celulares y de desarrollo básicos y por tanto se podrían abandonar ya definitivamente los viejos conceptos de DNA egoísta o basura (viejos, pero aun muy en boga en ciertos sectores científicos). El problema que comparten ambas visiones sobre los HERVs es dotar a unas secuencias de DNA de un carácter ontológico independiente, como si fueran entidades distintas del resto de las secuencias del genoma, capaces de dinámicas funcionales y evolutivas separadas, cuando la realidad es que unas y otras, aunque con orígenes distintos, conforman los genomas actuales, sin que ningún organismo (al menos pluricelular) se pueda entender -ni probablemente existir- sin ellas.

De todo esto se deriva la necesidad de revisar el significado biológico de los HERVs, su origen y sus implicaciones evolutivas desde una nueva perspectiva que los considera parte integral de nuestro genoma y son por tanto, desde el punto de vista genético, lo que nos hace ser lo que somos.

\section{Universalidad y especificidad de los retrovirus endógenos}

Tradicionalmente los retrovirus endógenos se han asociado a los Vertebrados, que es donde se descubrieron y donde se conocía la existencia de retrovirus infectivos, mientras que el resto de los organismos eucariontes presenta retrotransposones con LTRs, pero que los distintos autores no incluyen en la categoría de Retrovirus Endógenos (ERVs) ya que estos retroelementos aparentemente no podrían formar partículas al carecer del gen env. Sin embargo, resulta cada vez más claro que los retro- 


\section{Carlos Sentís}

virus endógenos están presentes en todos los grupos animales, al menos, en los que se han estudiado genómicamente en profundidad, desde que en los últimos años se han encontrado retrotransposones con LTR que además contienen el gen env (y son, por tanto, capaces de formar partículas) tanto en Artrópodos como en Nematodos (Tanda et al., 1994; Leblanc et al., 2000; Bowen y McDonald, 1999). Además, algunos de ellos se han demostrado infectivos, como gypsy y osvaldo en Drosophila, y muestran todas las características de los retrovirus infectivos (Kim et al., 1994; Pantazidis et al., 1999). Más aún, se han descrito recientemente provirus endógenos completos en plantas (Laten et al., 1998; Wright y Voytas, 1998; Peterson-Burch et al., 2000), y todos los retroelementos con LTRs, los ERVs de plantas e invertebrados, junto con los ya conocidos endógenos y exógenos en Vertebrados, constituyen un grupo monofilético (Capy et al., 1997), lo que significaría la presencia prácticamente universal de los ERVs en los genomas eucariontes.

Se ha hipotetizado que distintos tipos de virus podrían haber participado en el origen de la celúla eucarionte, como los fusellovirus de Archaea o el mycoplasmavirus L3, que habrían participado en la unión de bacterias primitivas para formar los primeros eucariontes (Sinkovics, 2001). Además, la maquinaria de replicación eucariótica parece haber derivado de los genes que codifican estas funciones en los virus DNA (Villareal y DeFilippis, 2000). A ésto habría ahora que añadir la posibilidad de que también los retrovirus participaran en el proceso que dio origen a la célula eucarionte, lo que explicaría la distribución en prácticamente todos los grupos eucariontes observada actualmente.

El mantenimiento de estas secuencias en estado funcional a lo largo de millones de años y el alto nivel de homología entre los distintos elementos presentes en especies muy distantes filogenéticamente son característicos de genes clásicos con funciones celulares bien definidas y necesarias. A pesar de esta amplia distribución filética, cada especie presenta su propio -y único- repertorio en tipología, cantidad y localización genómica de ERVs que la caracterizan y la distinguen del resto. Estas dos características -aparentemente contradictorias- de universalidad y a la vez especificidad de los ERVs se explica por su propio mecanismo dual de transmisión, vertical y horizontal, ya que los ERVs pueden convertirse en infectivos, es decir, en RVs, que, a su vez, en determinadas ocasiones pueden integrarse en la línea germinal, sufriendo mutaciones y recombinaciones durante el proceso de dispersión e integración.

Tras su inserción en la línea germinal para formar parte de los genomas, los ERVs pueden generar un elevado número de copias en diferentes localizaciones genómicas a través de la retrotransposición. A partir de 
aquí, se transmiten de modo vertical a la descendencia durante largos periodos de tiempo, pero acumulando mutaciones (debido en parte a la alta tasa de mutación de la RT) y con capacidad de recombinación entre ellas y con otras previamente presentes en el genoma, generando nuevas combinaciones (Kubo et al., 1996; Lindeskog et al., 1998) que pueden recuperar la infectividad, pero con características alteradas de especificidad celular y de huésped, lo que permite su paso a distintas especies por transmisión horizontal, donde se endogenizan y amplifican, volviendo a iniciarse el proceso. La fase de transmisión horizontal de los retrovirus tiene la ventaja como mecanismo evolutivo de que permite provocar un cambio genómico importante, afectando incluso a procesos de desarrollo o reproducción, en un número significativo de población, frente a la dificultad de expansión a la población de una mutación importante en un único individuo que afecte, por ejemplo, a la reproduccion, que nunca ha tenido una explicación adecuada. De este modo, las comparaciones filogénéticas de cada familia de ERVs es, en general, concordante con la filogenia conocida de los organismos que los presentan, mientras que, a mayor complejidad organísmica, aparecen mayor número de familias distintas, lo que implica sucesivas entradas de RVs a lo largo de la evolución. Pero también hay familias de ERVs específicas de determinados grupos, por lo que la actual distribución, tipología y número de ERVs en una especie debería recapitular su historia evolutiva. Sin embargo, la presencia de ERVs muy similares en especies muy alejadas permite identificar transmisiones horizontales entre grupos animales, que, aunque ocasionales, pueden ser importantes (un muy alto nivel de homología entre secuencias de especies muy alejadas evolutivamente se interpreta como transmisión horizontal). Varios ejemplos de transmisiones de RVs de este tipo entre especies se han detectado entre mamíferos placentarios, donde parecen ser relativamente frecuentes, incluyendo transmisiones entre el hombre y otros primates (Benveniste y Todaro, 1974; Li et al., 2001; Koralnik et al., 1994; Mang et al., 2000). Pero también se han postulado infecciones horizontales recientes entre especies pertenecientes a distintas clases de vertebrados (Martin et al., 1999), como el SNV aviar (spleen necrosis virus), que parece haberse transferido desde un equidna (Monotrema) para después sufrir una radiación adaptativa en algunas familias de aves; el otro caso es entre marsupiales y placentarios, concretamente un retrovirus endógeno de koala que se ha transferido al gibón como un RV exógeno altamente oncogénico e infectivo.

En el caso de la especie humana, que es la mejor conocida a nivel genómico por lo que se refiere a los retrovirus endógenos, se han identificado -de momento- 22 familias de HERVs (Tristem, 2000), algunas de 
las cuales pueden ser encontradas en especies muy alejadas filogenéticamente, aunque la mayoría son características de los primates. Dos de ellas, HERV-I y HERV-E, se pueden considerar ocupantes muy antiguos, ya que están en todos los vertebrados (Martin et al., 1997; Herniou et al., 1998), mientras que HERV-L se remonta a, como mínimo, antes de la radiación de los mamíferos, ya que se encuentra en todos los placentarios, y parece haber sufrido amplificaciones explosivas en algunos grupos, como Simios o Mus, pero no en otros cercanos filogenéticamente como Prosimios y Rattus, respectivamente (Benit et al., 1999).

Pero muchas de las familias de HERVs identificadas son específicas de Primates, algunas sólo de Catarrinos, y algunos miembros de estas familias (sobre todo de la superfamilia HERV-K) son únicas de la especie humana, bien como LTRs solitarias, bien como provirus completos con todos sus genes operativos, y no están presentes en ninguna otra especie (Barbulescu et al., 1999) ${ }^{1}$.

Asimismo, otros miembros de HERV-K están presentes en chimpancés y gorilas, pero no en humanos (Barbulescu et al., 2001), por lo que los distintos elementos de esta familia han continuado reinfectando la línea germinal en tiempos recientes en distintas especies de Homínidos tras su divergencia, y mantienen su capacidad de formar nuevos virus funcionales, puesto que algunos de ellos son polimórficos en las poblaciones humanas (Turner et al., 2001). Aunque falta mucho del genoma humano por conocer, y casi todo del genoma de chimpancé, se calcula que hay centenares de secuencias de este tipo específicas de la especie humana entre provirus completos y, sobre todo, LTRs solitarias, es decir, un repertorio único de genes estructurales y elementos reguladores, que contribuye a explicar nuestras diferencias genéticas con las especies próximas. A la vez, cada vez está más claro que las diferencias entre las especies próximas de Primates no radican en la existencia de muchos genes estructurales distintos, sino más bien en la expresión diferencial de los genes compartidos, es decir, las diferencias fundamentales son las que afectan a la regulación de los genes existentes, con ganancias y pérdidas de función específicas, o la expresión en tejidos y momentos de desarrollo diferentes (Brosius, 1999a, Gagneux y Varki, 2001; Hacia, 2001), eventos en los que las LTRs de HERVs pueden ser esenciales.

\section{Funciones celulares de los HERVs}

A partir de las funciones codificadoras que tienen los genes retrovirales gag, pol y env (Figura 1), se puede extrapolar que cuando estos genes 
Retrovirus endógenos humanos: Significado biológico...

presentes en los HERVs se expresan pueden producir muy diversos productos, tanto estructurales como enzimáticos, desde receptores de membrana (env), hasta proteínas de unión específica a secuencias determinadas de DNA (gag), que interaccionan con otros productos celulares. Por otro lado, la propia presencia de la RT (codificada por el gen pol) sigue siendo un misterio, ya que nadie sabe cuál puede ser realmente su función en un organismo eucarionte, puesto que aparentemente ningún proceso celular depende de ella. Teniendo en cuenta que tanto los HERVs como los otros retroelementos autónomos sin origen viral, como las LI$\mathrm{NEs}$, presentan el gen que codifica la RT, ésta sería la familia multigénica más repetida de todo el genoma, y probablemente el número de sus copias -aunque ligeramente distintas entre sí- sea probablemente mayor que la cantidad total de genes identificados en el último versión de la secuencia del Genoma Humano (The Genome Sequencing Consortium, 2001). ¿iY todo este material genético para codificar una proteína perfectamente dispensable por la célula!?

Los HERVs son biológicamente activos, tanto a nivel de RNAs transcritos, como de las proteínas que codifican, y son ya muchos los ejemplos de participación de los genes y las regiones reguladores retrovirales en las funciones celulares normales. Además, se expresan diferencialmente según los tipos celulares y tejidos, así como dependiendo del momento de desarrollo, de modo que están sometidos a una regulación espacio-temporal muy precisa (Schon et al., 2001; Blond et al., 2000: Mi et al., 2000). Muchas de las proteínas que producen son funcionales (Medstrand y Mager, 1998), aunque muchas de ellas sean truncadas, ya que presentan los motivos proteicos funcionales, como en el caso del gen env de HERV-H que produce proteínas incompletas pero con el dominio de transmembrana inmunosupresor (Lindeskog y Blomberg, 1997), o el gen gag de HERV-W con dominios parciales de cápsida y matriz capaces de unirse a DNA (Voisset et al., 2000). Los productos de los HERVs están plenamente integrados en el desarrollo, ya que algunos de ellos son necesarios para la propia diferenciación celular, puesto que son el sustrato sobre el que actúan potentes morfógenos, como el ácido retinoico y las BMPs (Bone Morphogenetic Proteins) sobre HERV-K. La activación de distintos miembros de la familia HERV-K por estos morfógenos parece ser un paso intermedio necesario en la diferenciación de células epiteliales y neuronales a partir de células embrionarias (Caricasole et al., 2000a y b).

La expresión y el procesamiento de estos genes provirales está controlada por sus LTRs así como por el conjunto de factores celulares que regulan la expresión génica, ya que las LTRs contienen secuencias respondedoras a hormonas (estrógenos, progesterona, glucocorticoides...) 
(Patience et al., 1997b; Medstrand et al., 1997) y a factores de transcripción, tanto ubícuos como específicos tisulares (De Parseval et al.,1999; Knossl et al.,1999), De este modo, una misma LTR puede desarrollar actividades distintas en diferentes líneas celulares (Baust et al., 2001) y, por el contrario, otras LTRs sólo manifiestan actividad promotora en un tipo celular determinado (Schon et al., 2001). Esta especificidad estricta de tipo celular depende de su secuencia, ya que la mantiene cuando se transfiere a ratón o cuando cambia de posición en el genoma (Casau et al., 1999), pero pequeñas mutaciones en su secuencia cambian la especificidad tisular de los genes que controlan (Sugimoto et al., 2001), por lo que se puede afirmar que contienen los elementos necesarios para su propia regulación espacio-temporal. Puesto que hay miles de LTRs solitarias dispersas por el genoma, muchas de ellas actúan sobre otros genes controlando su expresión, bien actuando como promotores o enhancers específicos de tejidos, o bien proporcionando señales alternativas de poliadenilación, con lo que se pueden obtener distintos productos proteicos de un solo gen con distintas actividades biológicas, e incluso dando como resultado productos completamente nuevos, como en el caso del gen PLA2L, mediante un splicing intergénico (para algunos ejemplos sobre las funciones de las LTRs, ver: Mager et al., 1999; Baust et al., 2000; Lavrentieva, 1998; Kowalski et al., 1999; Strazzullo et al., 1998; Medstrand et al., 2001; King y Francomano, 2001). El resultado de todas estas interacciones entre los HERVs y el resto de las secuencias y productos celulares es una impresionante diversidad de productos posibles que son utilizados según las necesidades celulares, pero a diferencia de otras secuencias, los HERVs son capaces de modelar el genoma de manera dinámica gracias a sus capacidades de recombinación y transposición. La capacidad de los HERVs de formar proteínas de fusión con otros genes genera una variedad combinatoria muy superior a la visión estática del simple número de genes como constructores de la realidad fisiológica: es evidente que no es lo mismo una proteína con dominios exclusivamente citoplasmáticos, que otra con el ligero añadido de un dominio de transmembrana de un gen env, localizando así su actividad en la membrana.

\section{Integración de las funciones de los HERVs en procesos fisiológicos complejos: el ejemplo de la placentación}

La expresión de RNAs y proteínas de diferentes HERVs se puede obervar en prácticamente todos los tejidos humanos, pero es especialmente conspícua, llegándose a formar retrovirus completos extracelula- 
res, en las células de la línea germinal (Nilsson et al., 1992), en tejidos embrionarios y, sobre todo, en placenta. De hecho, las primeras observaciones de partículas retrovirales se remontan a los años 70 en placentas normales (Imamura et al., 1976; Dirksen y Levy, 1977; Daniel y Chilton, 1978, revisado por Ueno et al., 1983 y Hohenadl et al., 1996), donde, además, se detecta una gran actividad de la transcriptasa inversa (Nelson et al., 1978; Larsson et al., 1994). La gran expresión de proteínas de diferentes familias de HERVs en este tejido ha sugerido (Boyd et al., 1993; Villareal, 1997; Harris, 1998) una función para ellos en el fenómeno mismo de la placentación, que, pese a su enorme importancia, es un proceso poco comprendido, y cuya aparición sigue siendo un interrogante evolutivo de primer orden.

Desde el punto de vista inmunológico, la madre debería rechazar al embrión por ser un tejido medio extraño, ya que expresa antígenos de origen paterno, pero, por supuesto este rechazo no se da; por otro lado, debe restringir el crecimiento fetal para que la invasión que, de todas maneras, supone de los tejidos maternos esté controlada (Ober, 1992 , Loke y King 1997). Los retrovirus son generalmente inmunosupresores y fusogénicos, gracias a las características de las proteínas codificadas, principalmente, por el gen env, lo que convierte a sus versiones endógenas -los ERVs- en candidatos idóneos para superar este aparente conflicto, ya que sus productos mantienen las mismas propiedades (Denner, 1999). Los retrovirus endógenos estarían implicados en la protección del feto de dos maneras: fusionando las células del trofectodermo para formar un sincitio e inmunosuprimiendo las células maternas en la vecindad inmediata de la placenta. De hecho, se detectan partículas retrovirales endógenas en trofoblasto pero no en la masa de células interna que dará lugar al embrión propiamente dicho (Stromberg y Benveniste, 1983; Johnson, 1993) y, puesto que el trofoblasto protege al embrión de los macrófagos maternos (Sionov et al., 1993), el papel que jugarían los HERVs sería mediante una infección local sobre las células circundantes, de modo que sólo provocaría la inmunosupresión de los macrófagos maternos inmediatamente próximos, que serían los encargados del rechazo fetal, mientras que el resto del sistema inmune materno seguiría defendiendo a la madre y al feto de los agentes patógenos ${ }^{2}$. Por otro lado, el sincitiotrofoblasto es una estructura única de los placentarios que constituye la interfase feto-materna y contribuye a la limitación del crecimiento fetal, y se forma gracias a una proteína, la sincitina, que permite la fusión celular del citotrofoblasto y es el producto del gen env de un miembro de la familia HERV-W (Mi et al., 2000; Blond et al., 2000), completamente funcional, tanto en su dominio inmunosupresor como en su 
dominio fusogénico. Al diferenciar terminalmente las células del trofoblasto y formar el sincitio, la sincitina limitaría la capacidad invasiva del trofoblasto sobre el endometrio. Además, otros muchos HERVs de diferentes familias (HERV-K, HERV-F, etc.) se expresan durante la placentación y participarían activamente en el proceso, como ERV3 que se ha demostrado necesario para la correcta diferenciación de las células del trofoblasto en cultivo (Lin et al., 1999). Sin embargo, se da la paradoja de que HERV-W es una familia de HERVs propia de los primates catarrinos, mientras que la placentación es un fenómeno general de todos los euterios. Esto se puede explicar porque, debido a la redundancia característica de los HERVs, existen múltiples genes env con las mismas -o similares- capacidades inmunomoduladoras y fusogénicas, por lo que es probable una transcomplementación de funciones entre las distintas secuencias retrovirales y sus productos, lo que no sería raro, ya que la redundancia funcional es una característica de los genes con funciones esenciales para la supervivencia del organismo. Esto explicaría, además, las observaciones de implantaciones y embarazos normales en las mujeres que presentan el ERV3 mutado no funcional (De Parseval y Heidmann, 1998). Es más, las partículas retrovirales observadas no pueden ser exclusivamente de HERV-W ya que, aunque el gen env sea funcional, parece que los genes gag y pol de este provirus no son funcionales al contener múltiples codones de terminación, por lo que la formación de partículas exige la colaboración de productos de otros HERVs, cuyos RNAs son detectados en las partículas, como HERV-K. De hecho, la sincitina puede transcomplementar a otros retrovirus exógenos defectivos, como el HIV sin el gen env funcional, y son capaces de formar partículas con ellos (An et al., 2001). La participación de varios HERVs en este proceso explicaría las diferencias en el proceso de implantación en las distintas especies de mamíferos: por ejemplo, el sincitiotrofoblasto humano es diferente del de ratón ya que mientras que el humano se forma por fusión de células mononucleadas, el de ratón se forma por división sin citocinesis, por lo que aunque sea una estructura tan fundamental, los procesos para su formación pueden haber sido diferentes durante la evolución, lo que sería un ejemplo más de estructuras homólogas que utilizan distintas rutas de desarrollo (Wray y Abouheif, 1998).

Pero las funciones de los HERVs en la placentación no son únicamente las derivadas de las propiedades de sus partículas, sino que otras secuencias retrovirales están implicadas en la complicada regulación de la fisiología placentaria y el desarrollo fetal. Por ejemplo, el factor de crecimiento PTN (pleiotrofina) es ubícuo, pero en humanos tiene además un promotor específico de trofoblasto en una LTR de HERV-E, de modo que 
Retrovirus endógenos humanos: Significado biológico...

en este tejido se forman productos de fusión HERV-E-PTN que contribuyen a las funciones invasivas y proliferativas que le son propias (Schulte et al., 1996,). Por otro lado, una LTR retroviral proporciona el enhancer específico de placenta al gen de la leptina (Bi et al., 1997). Este enhancer promueve una alta tasa de expresión de este gen en placenta, concretamente en sincitiotrofoblasto, y contribuye al incremento de las concentraciones circulantes de leptina durante el embarazo. Además de las funciones conocidas de la leptina como regulador del equilibrio energético, en placenta se le atribuye un papel angiogénico e inmunomodulador mediante mecanismos autocrinos y paracrinos, y parece afectar al crecimiento fetal y al desarrollo mediante su unión a los receptores de leptina específicos presentes en los órganos fetales (Ashworth et al., 2000; Henson y Castracane, 2000). A su vez, el receptor de leptina placentario presenta varias isoformas como resultado del splicing alternativo del gen OBRa, una de las cuales se genera mediante la adición de 67 aminoácidos procedentes de otra LTR (esta vez de un retrovirus distinto de la familia HERV-K) (Kapitonov y Jurka, 1999) y sería interesante conocer las proporciones de las distintas isoformas en la placenta y en los tejidos fetales, ya que en el caso de otros genes bajo el control de dos promotores -uno retroviral y otro no-, la isoforma promovida por la LTR retroviral es mayoritaria o exclusiva en placenta, mentras que en otros tejidos los tránscritos se generan de ambos promotores de modo equivalente (Medstrand et al., 2001). Por supuesto, la desregulación de la leptina placentaria (y/o de sus receptores, que es funcionalmente lo mismo) se ha asociado con problemas en el embarazo, como preeclampsia y diabetes materna, retraso en el crecimiento fetal, insuficiencia placentaria, etc., lo que significa que su expresión, controlada por HERVs, está exquisitamente controlada e integrada en el entramado físiológico.

La enorme complejidad del proceso de placentación, la necesidad de sincronización en la acción de múltiples genes para su correcto funcionamiento, la generación de estructuras previamente inexistentes, como el sincitiotrofoblasto, así como el control preciso de su papel invasivo-que no debe llegar a colonizar los tejidos maternos-, a la vez que se inhibe de un modo controlado el sistema inmune materno para evitar el rechazo del embrión parcialmente alogénico, hace imposible que todas estas funciones surgieran por mutaciones o duplicación y divergencia de genes individuales de modo gradual. A la vez, la multiplicidad de funciones celulares y tisulares de los HERVs y la cantidad y diversidad de ellos que participan en el proceso de placentación, hace poco probable su incorporación paulatina a ese proceso, ya que se necesita la acción coordinada y simultánea de todos ellos para la propia existencia del proceso. Por el 
contrario, un proceso de integración retroviral y posterior amplificación y retrotransposición explosiva, como los observados en condiciones de shock genómico por stress ambiental, (Wessler, 1996; Kidwell y Lisch, 1997) podría explicar mejor la generación de distintas funciones coordinadas en la red genética. Por otro lado, la interpretación de que esos genes puedan ser exaptados para solucionar el conflicto genético de la placentacion (Haig, 1992), según el cual una vez aparecida la placentación, los embriones generan la inmunosupresión para que la madre no los rechace, y la madre adquiere caracteres que restringen el crecimiento fetal para no ser invadida, no se sostiene, ya que sin estos caracteres (y los HERVs que los determinan) el mismo proceso de la placentación, simplemente, no podia haber existido.

\section{Efectos genómicos de los HERVs}

La existencia de miles de secuencias de las distintas familias de HERVs en el genoma humano, que presentan homologías parciales y capacidad de retrotransposición, es una fuente enorme de variabilidad y plasticidad genómica. Gracias a sus homologías facultan las recombinaciones entre distintas regiones del genoma, promoviendo en general reorganizaciones genómicas y, en algunos casos concretos, duplicaciones génicas, tanto de sí mismas, como de cualquier gen que esté flanqueado por las repeticiones (Shen et al., 1994; Andersson et al., 1998). También podrían contribuir a la aparición de las duplicaciones de segmentos cromosómicos completos que se observan en el genoma humano (The Genome Sequencing Consortium, 2001) y, como otros elementos móviles, producir otras reordenaciones cromosómicas (Caceres et al., 1999; Gray, 2000). Puesto que el movimiento de los HERVs por el genoma se debe a su propia capacidad de retrotransposición -es decir, con un intermediario de RNA y la acción de la RT-, la consecuencia más inmediata es la amplificación del propio genoma. De hecho, aunque la mayoría de los HERVs son defectivos, se pueden dispersar por el genoma mediante transposiciones intracelulares (Tchenio y Heidmann, 1991), lo que implica que existe transcomplementariedad entre sus distintos productos. Aunque todos los retroelementos autónomos movilizan preferentemente el RNA que codifican, sus proteínas pueden actuar en trans para promover la retrotransposición de otros elementos defectivos y otros RNAs celulares (Wei et al., 2001). Por su capacidad de movimiento pueden adquirir nuevas funciones dependiendo de su nueva situación genómica y bajo qué secuencias reguladoras se dispongan, o, a la inversa, dotar de 
Retrovirus endógenos humanos: Significado biológico...

nuevos elementos reguladores en cis a otros genes, que supongan un nuevo patrón de expresión (como en el caso de uno de los genes de la amilasa, en el que la integración de un HERV le da capacidad de expresión en saliva y no sólo en pancreas (Samuelson et al., 1990; Ting et al., 1992)). También pueden combinarse con otras secuencias codificantes dando lugar a nuevas formas funcionales y existen múltiples ejemplos de tránscritos de fusión entre genes y secuencias de HERVs. De hecho, se calcula que, al menos el $4 \%$ de los genes contienen retroelementos insertados que se han convertido en exones nuevos (Nekrutenko y Li, 2001).

La integración de HERVs produce además diversidad alélica en las poblaciones, como se ha demostrado en la región del Complejo Mayor de Histocompatibilidad (MHC) (Tassabehji et al., 1994; Dawkins et al., 1999; Kulski et al., 1999;) y puede producir respuestas individuales diferenciales ante determinadas enfermedades, sobre todo contra las infecciones virales exógenas (Dangel et al., 1994; Schneider et al., 2001). La propia diversidad y complejidad del MHC se puede atribuir a las inserciones de distintos HERVs y a las recombinaciones entre ellos que han producido las duplicaciones de grupos génicos completos dentro del complejo, como el módulo de cuatro genes RCCX, que aparece de una a tres veces en la población (Shen et al., 1994). Por supuesto, no todos los efectos de los HERVs sobre el genoma son constructivos: si el elemento movilizado se inserta un una secuencia codificante se puede producir la inactivación de ese gen por mutagénesis insercional, convirtiéndose en delétereo o en letal, dependiendo de la función afectada, como ha ocurrido con la Distrofia Muscular de tipo Fukuyama (Kobayashi et al., 1998). Mientras que las mutaciones puntuales son un medio lento de cambio genómico, y por tanto son herramientas poco satisfactorias para la generación de diversidad estructural y funcional del genoma, los reordenamientos mediante recombinación y tansposición mediados por los HERVs son mucho más eficientes para la remodelación global de los genomas, que es una condición previa e indispensable para la evolución de los organismos.

Otro efecto de los HERVs sobre el genoma, en colaboración con otros retroelementos autónomos, es la formación de genes y pseudogenes procesados (retrogenes y retropseudogenes), es decir, copias de los RNAs producidos por otros genes a DNA mediante transcripción inversa con la $\mathrm{RT}$, que son integrados en el genoma, provocando su duplicación funcional, ya que contienen la parte informacional de esos genes, y con la posibilidad de adquirir nuevas funciones celulares. La gran mayoría de estas secuencias amplificadas derivan de RNAs pequeños nucleares o de tRNAs (es decir, RNAs que no se traducen a proteínas, pero que tienen propiedades estructurales -y enzimáticas) y constituyen las SINEs, que, en 
conjunto, ocupan aproximadamente el $15 \%$ del genoma y cuyas funciones, esencialmente reguladoras, han sido objeto de excelentes revisiones (Smit, 1999; Brosius, 1999a). El otro grupo de genes procesados deriva de RNAs mensajeros maduros y por tanto generalmente carecen de intrones y de secuencias promotoras, pero mantienen toda la secuencia que codifica proteína. Pese a no tener la región promotora, muchos de ellos se transcriben debido a que su reubicación genómica les ha colocado bajo el control de otros promotores o de las LTRs con actividad promotora que están dispersas por el genoma. De este modo, los retrogenes a menudo se expresan en distintos tipos celulares o momentos de desarrollo que los genes originales de los que derivan, por lo que pueden tener funciones celulares alteradas o completamente nuevas (Brosius, 1999b). Parte de estos genes son aparentemente no operativos (retropseudogenes) ya que presentan mutaciones puntuales, inserciones o deleciones, sin embargo, no se pueden calificar de inactivos ya que muchos de ellos se transcriben y en ocasiones se traducen, aunque desconocemos las posibles funciones de sus productos. En todo caso, la existencia de miles de genes procesados supone un acervo de variabilidad informacional muy superior a la duplicación génica tradicional, ya que supone la capacidad de asociar unidades codificadoras completas con elementos reguladores completamente distintos de los que tenía, con el consiguiente potencial evolutivo que ello supone. En general, los retrogenes derivan de genes ampliamente expresados y altamente conservados, por lo que este proceso es uno de los pocos que permiten de modo inmediato nuevas funciones más específicas en el complejo entramado molecular de la célula. Está claro por tanto que los retrogenes son una fuente de variabilidad genómica -un tipo de duplicación funcional, pero con patrones de expresión nuevos- que hace evolucionar a los genomas. El problema sigue siendo cómo llegan los retrogenes a la línea germinal para extenderse a la población de modo mendeliano.

Puesto que los retrogenes forman parte de los genomas, los eventos de retrotransposición e integración por los que se generan han tenido que suceder en las células de la línea germinal. Esto es relativamente fácil de explicar en el caso de que los genes de los que se derivan se expresen en esas células o durante los primeros estadios del desarrollo embrionario. No resulta sencillo de explicar mediante mecanismos convencionales, sin embargo, cuando los genes originales se expresan exclusivamente en un tejido somático, ya que su RNA mensajero sólo se expresará en ese tejido, y para llegar a la linea germinal hace falta un vehículo que interconecte las líneas somática y germinal y consiga trasladar un RNA desde una celula somática a una célula germinal y en ella retrotranscribirlo e 
Retrovirus endógenos humanos: Significado biológico...

integrarlo en el genoma. El mecanismo más probable para movilizar RNAs entre distintas células y que además puede integrarlos en la línea germinal es la transfección retroviral (retrotransfección o retrofección), es decir, que las partículas retrovirales serían un vector de trasmisión de información genética de la línea somática a la germinal. De hecho, ya dijimos que el propio origen de los retrovirus endógenos es la infección retroviral de las células germinales, lo que implica la existencia de este proceso, aunque sea poco frecuente. Si un RNA celular se encapsula en una partícula vírica, puede ser transportado por ésta en su infección de otras células, retrotranscrito e integrado como secuencia de DNA en el genoma de las células germinales ya que ésto forma parte del ciclo vital del retrovirus. Su carácter infectivo le permite además afectar a un cierto número de iindividuos simultáneamente $\mathrm{y}$, de este modo, la informacion producida por las células somáticas en forma de RNAs se transfiere ocasionalmente a la linea germinal, heredándose a partir de ahí de modo mendeliano y se observan en el genoma como retrogenes y retropseudogenes.

\section{Las reordenaciones genómicas producidas por los HERVs dependen de las condiciones ambientales}

La dispersión de los retroelementos se asocia a menudo con situaciones de bruscos cambios ambientales. Ya desde los trabajos pioneros de McClintock con elementos transponibles (ver p.e. su conferencia de recepción del Premio Nobel, publicada en Science: McClintock, 1984), se sabe que determinadas condiciones externas pueden provocar cambios genómicos bruscos (un estado de shock genómico) y las observaciones indican que se produce una transposición concertada de distintos tipos de elementos transponibles, tanto DNA (transposones), como RNA (retroposones y retrovirus endógenos) (Wessler, 1996; Kidwell y Lisch, 1997). Las situaciones de stress ambiental pueden ser muy diversas e incluyen la endogamia forzada por la selección artificial de razas (Mang et al., 2001), la hibridación interespecífica (Labrador et al., 1999), los cultivos celulares de larga duración (Pouteau et al, 1991), y la presencia de agentes mutagénicos ambientales, como los rayos ultravioleta (Hohenadl et al., 1999). Por ejemplo, los análogos de bases, como la iododeoxiuridina y la azacitidina inducen la formación de partículas virales infectivas a partir de provirus endógenos en ratón (Khan et al., 2001).

Los HERVs, como parte de su expresión normal en las células, son inducibles en ciertos tejidos y momentos de desarrollo (Svensson et al., 
2001), lo que implica que pueden responder a distintas señales externas e internas, pero se activan especialmente tras la infección con otros virus y bacterias (Hara et al., 1981). Por ejemplo, es bastante conocido (Stevens et al., 1999) que la mayoría de los infectados por HIV muestran sobreexpresión de HERVs. En la especie humana precisamente se han asociado los HERVs con algunas enfermedades ya que algunos tumores, los tejidos afectados en pacientes autoinmunes y, recientemente, tambien en esquizofrénicos, contienen partículas retrovirales producidas por HERVs, y algunas de estas partículas tienen un probado carácter infectivo (Christensen et al., 2000). La reactivación de algunos HERVs se puede observar, incluso, durante el envejecimiento, aunque no parece tener implicaciones en ninguna enfermedad asociada con este proceso (Puech et al., 1997). En cada uno de estos casos parece claro que ha habido una desregulación en la expresión de los HERVs -y de otros muchos genesen situaciones de fallo celular generalizado, inducido por factores genéti$\cos$ y xenogenéticos. Este cambio de regulación puede aumentar la expresión de un determinado HERV, como en el caso de los teratomas que muestran partículas de HERV-K (mientras que en las células germinales normales de los que derivan esos tumores la expresión del mismo HERV es muy pequeña), o, por el contrario, es la falta de expresión de un determinado HERV la que se asocia con un desarrollo neoplásico, como ERV3, muy expresado en placentas normales, pero ausente en coriocarcinoma (Kato et al., 1990). Pero la desregulación también puede implicar un cambio en el momento de desarrollo o el lugar en que se expresan, como parece ser el caso de MSRV/HERV-W que se expresa de modo normal en placenta (Blond et al., 1999) y que se detecta en las partículas retrovirales observadas en los pacientes de esclerosis múltiple, pero no en los mismos tejidos de los individuos sanos (Perron et al., 2000). En este caso, parece que la infección previa por el virus de Epstein-Barr (un herpesvirus) es un prerrequisito para el desarrollo de la enfermedad (Häär y Munch, 2000), por lo que el fallo de regulación de los HERVs sería una respuesta a otra infección viral. Es decir, la activación de los HERVS formaría parte de la respuesta celular ante situaciones de agresión externa, de modo que en determinadas circunstancias de graves crisis ambientales se produciría un incremento explosivo en su actividad de retrotransposición que posibilita las reordenaciones genómicas que se vieron en el apartado anterior, y, al formar partículas, aumentaría su capacidad de retrotransfección tanto de ellos mismos como de otros RNAs celulares para su integración estable en la línea germinal. La expresión de los HERVs en la línea germinal permitiría y potenciaría su movimiento y dispersión en la población de modo infectivo en momentos concretos de 
Retrovirus endógenos humanos: Significado biológico...

su historia evolutiva, mientras que en los periodos intercríticos estarían sometidos a una estricta regulación somática de su expresión para mantener la estabilidad genómica ante ambientes estables, restringiendo, entre otros efectos, la mutagénesis insercional y los resultados perniciosos de su expresión inadecuada. De este modo, las situaciones de stress organísmico o celular podrían provocar, en momentos evolutivos concretos, cambios genómicos extensos, sobre todo funcionales, y la activación de todos los retroelementos mediados por los HERVs, lo que contribuiría significativamente a la diversidad de los fenotipos, que, al fin y al cabo, son las unidades básicas del proceso evolutivo.

Desde una perspectiva evolutiva esta mutabilidad inducida por condiciones ambientales puede ser muy importante y se diferencia de otros procesos mutacionales clásicos por su potencial diversidad estructural y funcional, e implica que las tasas de cambio genómico no son, ni mucho menos, constantes, sino que aparecen en avalanchas de modo repentino, tras largos periodos de aparente inactividad transposicional, como sucede con otros elementos móviles (Wessler, 1996). Esto podría explicar las explosiones retrotransposicionales esporádicas en momentos evolutivos que coinciden con grandes reordenaciones organísmicas, como la aparición de nuevas familias (Devor, 2001; Goncalves et al., 2000). Incluso se ha conjeturado (Travis, 1992) que estas explosiones transposicionales -incluyendo, no solo HERVs, sino todos los elementos genéticos móvilespodrían ser responsables de las grandes radiaciones evolutivas, como la denominada explosión del Cámbrico, en la que aparecen repentinamente múltiples organizaciones animales distintas. En todo caso, estas reorganizaciones genómicas extensivas producidas por los HERVs en momentos concretos, ante situaciones ambientales críticas, podrían explicar una parte de las discontinuidades evolutivas observadas, por lo que se pondría de manifiesto su enorme importancia como mecanismo de cambio en los procesos macroevolutivos.

\section{Las nuevas combinaciones genómicas funcionales producidas por los HERVs contribuyen a la diversidad morfológica}

Los avances de la Genética y de la Biología del Desarrollo en los últimos años, con las primeras versiones casi definitivas de genomas completos, han puesto de manifiesto el alto nivel de complejidad y de interacción en red que exige el funcionamiento celular y organísmico, mucho más parecido a la teoría de sistemas complejos que al mecanicismo imperante en las explicaciones tradicionales del papel de los genes en la de- 
terminación del fenotipo. Las relaciones funcionales entre genotipo y fenotipo son extraordinariamente complejas, ya que genes homólogos no especifican necesariamente estructuras homólogas y viceversa (Wray, 1999), y ya no es posible considerar a los genes como unidades independientes que determinan todos los caracteres observables, porque esa supuesta autonomía génica difícilmente explicaría los procesos de diferenciación y desarrollo, que son los que, en ultimo término, identifican y definen a cada uno de los seres vivos. Eran los tiempos de la hipótesis de "un gen-un enzima», de modo que cada gen codificaba una proteína y se asociaba a un fenotipo particular. Lo que nos dice la genómica es que los sistemas genéticos son redundantes y cada gen está constituido por una serie de modulos reguladores y codificadores que están sujetos a múltiples mecanismos de cambio (Dover, 2000), que permiten la aparición y dispersión de nuevas combinaciones de módulos que contribuyen de modo significativo a la evolución de los fenotipos. Entre estos mecanismos juegan un papel fundamental los HERVs, ya que pueden promover,no sólo la construcción de estructuras nuevas, sino su dispersión a la población en momentos evolutivos concretos, coincidentes con cambios medioambientales profundos que provocan sus explosiones retrotransposicionales y consiguiente remodelación de los genomas.

El hecho de que existan múltiples secuencias reguladoras -miles de LTRs dispersás por el genoma-, que están implicadas un distintos procesos de diferenciación y desarrollo, podría ayudar a comprender cómo se puede producir este proceso. Si a esto le añadimos que, por la mera presencia de los HERVs, el genoma puede disponer de miles de secuencias que codifican dominios proteicos funcionales con capacidad de formar productos quiméricos con otras secuencias codificantes, cuya función última depende del tránscrito y proteína que finalmente formen, obtendremos un enorme bagaje combinatorial al que hay que sumar los cambios que sin duda se producirán en sus interacciones con el resto de los elementos que componen la red genética. Estos intercambios entre secuencias reguladoras y las secuencias controladas por ellas ofrecen más posibilidades de cambio morfológico y evolutivo que aquellos cambios estructurales que afecten a sus actividades propiamente bioquímicas. La posibilidad de que estas secuencias reguladoras adquieran nuevas funciones de desarrollo, perdiendo o no las anteriores funciones, hace relativamente innecesaria la aparición de nuevos genes: basta con dotar a los genes existentes de nuevas composiciones modulares. Esto no significa que otros mecanismos no sean posibles o no puedan coexistir como factores del cambio genético, pero hace mucho más factible la comprensión de la realidad observada, que, lejos de seguir siempre un patrón 
Retrovirus endógenos humanos: Significado biológico...

único de duplicación y divergencia gradual, parece explicarse mejor mediante la combinación de elementos preexistentes que alteran radicalmente sus funciones. El hecho de que gupos tan alejados filogenéticamente como Artrópodos, Nematodos y Vertebrados compartan gran parte de los genes directamente implicados en desarrollo, pese a mostrar morfologías y fisiologías tan diferentes, implica que los mismos genes pueden tener funciones distintas en distintos entornos genómicos. Mientras que gran parte de los genes fundamentales están presentes en todas las organizaciones organísmicas, lo que es tremendamente variable entre ellas es el tipo y la distribución de los elementos móviles, incluyendo las secuencias retrovirales. Es decir, que son esencialmente los mismos genes, pero distintos elementos reguladores, integrados todos ellos en una compleja red genética funcional, los que cambian funcionalmente durante el curso de la evolución, y que combinaciones nuevas de unos y otros pueden ser la base de las novedades morfológicas que diferencian a los distintos grupos. Siendo ésto así, no es posible seguir considerando a los genes como la unidad de cambio evolutivo, sino que el proceso evolutivo operará sobre las distintas partes funcionales del genoma: los elementos reguladores que determinan cuándo, cuánto y dónde se expresan las unidades codificantes, y si a estas unidades codificadoras las diseccionamos según sus propiedades funcionales en los distintos dominios proteicos, no sólo se obtiene un mayor -exponencialmente mayor- número de posibilidades de cambio, sino que obliga a modificar los modelos actuales sobre los que se explican las observaciones. Este cambio de unidad evolutiva, del gen a las distintas partes que pueden ser funcionales en el genoma, considera la modularidad de elementos genómicos funcionales, su capacidad combinatoria y su expresión en red, como una unidad de orden superior sobre la que construir los modelos que expliquen el cambio evolutivo. Un cambio de expresión de un gen (de lugar o de momento) puede provocar un nuevo juego de relaciones en el entramado de relaciones genes-RNA-proteínas, generando propiedades alteradas o completamente nuevas, es decir, cambios fenológicos, a veces sutiles, a veces bruscos. Es interesante que la inmensa mayoría de los retroelementos que forman parte de las regiones codificadoras lo hacen como exones nuevos, es decir, que una vez integrados en un intrón, un cambio de procesamiento los convierte en parte de la proteína codificada, dotando a la nueva proteína de características nuevas, bien de respuesta a otros factores, bien de unión específica a otras secuencias, o de lugar intracelular de actuación, con los efectos pleiotrópicos en la fisiología celular que ésto puede implicar y que son típicos de cualquier sistema complejo que funciona en red. 


\section{Carlos Sentís}

La existencia de retroelementos, y sobre todo de HERVs, implica que las células contienen toda la maquinaria necesaria para que opere una ingeniería genética natural que responde plásticamente a las condiciones ambientales en que se desarrolla y permite nuevas combinaciones de elementos informacionales. Su existencia implica que el genoma no es una entidad sujeta a una tasa de variación constante, sino que es fluido y está sujeto a reorganizaciones masivas, episódicas, y no aleatorias, que son capaces de producir nuevas arquitecturas funcionales.

\section{Algunas implicaciones prácticas del significado evolutivo de los HERVs}

Por último, es necesario hacer una pequeña reflexión sobre la importancia que puede tener el cambio de enfoque teórico respecto al significado y funciones de los HERVs en el ámbito aplicado de la salud humana. La concepción de que los HERVs son secuencias constitutivas de nuestro genoma que realizan diferentes funciones celulares y fisiológicas, y no parásitos egoístas que sólo pueden causar problemas, es decir, enfermedades, puede cambiar alguno de los planteamientos que se están utilizando en el manejo de los retrovirus y las enfermedades retrovirales en biomedicina. En primer lugar, la utilización de agentes antirretrovirales inespecíficos en el tratamiento de enfermedades somo el SIDA puede, además de detener la replicación del HIV, alterar las funciones normales desempeñadas por los HERVs. Por un lado, los análogos de base, como el AZT, impiden la replicación de los RVs infectivos, pero pueden activar los HERVs en tejidos o momentos donde no deberían expresarse, como sucede con otros productos similares (Khan et al., 2001), y puede interferir con sus funciones normales, ya que inhibe la RTs, en aquellos tejidos donde su función es necesaria. No se puede precisar el alcance de estos efectos de inhibición/activación puesto que los efectos de los HERVs son mayoritariamente desconocidos, así como sus interacciones con otros productos celulares y sus posibles reacciones ante los factores ambientales, sobre todo cuando actúan en periodos críticos del desarrollo embrionario, por ejemplo, durante la implantación, donde los HERVs son muy activos y necesarios como se vió en apartados anteriores.

En segundo lugar, también puede tener interés práctico en la discusión sobre la utilización de órganos de origen animal para su trasplante a seres humanos-xenotrasplantes-. Al igual que el genoma humano está plagado de HERVs, todos los genomas animales contienen retrovirus endógenos aunque en distinto número y de distinto tipo y, en concreto, 
los cerdos (que son los mejores candidatos como factorías de órganos para xenotrasplantes) tienen su propio repertorio (de PERVs) que aún no es del todo conocido (Mang et al., 2001). Sin embargo, el comportamiento de los PERVs conocidos en cultivo resulta alarmante, ya que cuando cambian de entorno celular -por ejemplo, en un cultivo mixto de células porcinas y humanas- pueden activarse y formar partículas infectivas para las células humanas con las que entran en contacto (Patience et al., 1997a). Este hecho era predecible desde el supuesto de que los retrovirus endógenos responden a las condiciones ambientales y que, por su capacidad de recombinación, las partículas formadas pueden adquirir propiedades nuevas, por ejemplo en su tropismo, y traspasar la barrera de especie que usualmente se observa en los RVs infectivos y, por tanto, con el potencial de provocar una infección zoonótica en la especie humana. Aunque es comprensible la presión social por parte de los enfermos que necesitan ser trasplantados (sobre todo en los países con baja tasa de donación de órganos, como en EEUU), es un riesgo inaceptable continuar con este tipo de experimentación en pacientes humanos, ya que, aunque los resultados hasta ahora han sido fulminantes, con resultado de muerte inmediata, es más que una posibilidad que tras uno de esos experimentos aparezca un nuevo RV infectivo, cuyas características de tropismo y transmisión sean completamente nuevas, con la posibilidad de provocar una nueva pandemia, y, por tanto, con efectos potencialmente devastadores para la especie humana.

Por último, pero muy relacionado con lo anterior, está la cada vez mayor utilización de vectores retrovirales, previamente inactivados en alguno de sus genes, en protocolos experimentales de terapia génica. En primer lugar, la introducción de estos vectores puede provocar respuestas celulares por parte de los HERVs, o bien interaccionar con ellos interfiriendo con sus funciones normales. En segundo lugar, ya no se podría establecer la barrera entre terapia génica somática y terapia germinal -esta última prohibida en todos los países- porque siempre existe la posibilidad de que esos vectores retrovirales, aún utilizados en células somáticas, alcancen la línea germinal como, aunque en ocasiones especiales, pueden hacer los RVs, llevando consigo el carácter que hayamos introducido. Esto ya ha sucedido en la fase experimental de algunos protocolos de terapia en animales (Reaves et al., 1999) y no hay razón para pensar que no pudiera suceder en su aplicación a humanos. A partir de su inserción en la línea germinal este carácter se transmitiría a toda la descendencia. El que los vectores sean defectivos no supondría ningún obstáculo, porque existiendo miles de HERVs, y teniendo en común la maquinaria de retrotransposición, la posibilidad de transcomplementa- 
ción entre productos génicos de HERVs y de los vectores que hayamos añadido es muy alta. De hecho, uno de los genes de los miembros de la familia HERV-K, el cORF, tiene las mismas funciones -aunque no se parece nada en su secuencia- que la proteína Rev del HIV y es capaz de complementar experimentalmente sus funciones cuando el HIV es defectivo para Rev (Yang et al., 1999). Todos estos ejemplos ponen de manifiesto la obligatoriedad de comprender mejor las funciones normales de los HERVs -así como sus posibles fallos-, antes de que una experimentación precipitada, poco o mal sustentada desde el punto de vista teórico, o partiendo de un paradigma erróneo, como que los HERVs forman parte del DNA basura o parásito, que no sirve para nada, pueda tener efectos desastrosos irreversibles.

Todas las revisiones de este tipo suelen acabar con la necesidad de profundizar en la investigación de laboratorio y en la obtención de más datos para resolver las incógnitas y dudas que quedan abiertas. En este caso, y sin despreciar la aportación contínua de datos, lo que hace falta es una tarea de síntesis y comprensión de los que ya poseemos (miles de artículos, en lo que se refiere al tema que nos ocupa) y una tarea de reflexión multidisciplinar, partiendo de un punto de vista holístico y abierto a diversas posibilidades teóricas, sin la constricción que suponen los paradigmas previos en los que se tiende a encajar -muchas veces de modo forzado- los resultados disponibles.

\section{Notas}

1 Resulta curioso que algunas de estas secuencias retrovirales específicamente humanas se han localizado en regiones genómicas asociadas con la asimetría cerebral y el lenguaje, y se encuentran desreguladas en pacientes esquizofrénicos (Kim et al., 1999; Karlsson et al., 2001).

2 Resulta sorprendente sin embargo que, en ocasiones, los efectos de enfermedades autoinmunes, como la artritis reumatoide, e incluso las generalizadas alergias disminuyen durante el embarazo, sugiriendo una alteración inmunológica no sólo a nivel local, sino a nivel sistémico.

\section{Bibliografía}

AN, D. S.; XIE, Y. M. y CHEN, I. S. (2001). Envelope gene of the human endogenous retrovirus HERV-W encodes a functional retrovirus envelope. J. Virol. 75, 3488-3489.

Andersson, G., Svenson, A. C., SetTerblad, N. y RAsk, L. (1998). Retroelements in the human MHC class II region. Trends Genet. 14, 109-114.

Ashworth, C. J., Hoggard, N., Thomas, L., Mercer, J. G., Wallace, J. M. y Lea, R. G. (2000). Placental leptin. Rev. Reprod. 5, 18-24. 


\section{Retrovirus endógenos humanos: Significado biológico...}

Barbulescu, M., Turner, G., Seaman, M. I., Deinard, A. S., Kidd, K. K. y Lenz, J. (1999). Many human endogenous retrovirus $K(H E R V-K)$ proviruses are unique to humans. Curr. Biol. 9, 861-868.

Barbulescu, M., Turner, G., Su, M., Kim, R., Jensen-Seaman, M. I., Deinard, A. S., KIDD, K. K. y LENZ, J. (2001). A HERV-K provirus in chimpanzees, bonobos and gorillas, but not humans. Curr. Biol. 11, 779-783.

Baust, C., Seifarth, W., Germaier, H., Hehlman, R. y Leib-Mosch, C. (2000). HERV-KT47D-related long terminal repeats mediate polyadenylation of cellular transcripts. Genomics 66, 98-103.

Baust, C., Seifarth, W., Schon, U., Hehlmann, R. y Leib-Mosch (2001). Functional ac tivity of HERV-K-T47D-related long terminal repeats. J. Virol. 283, 262-272.

Benit, L., Lallemand, J. B., Casella, J. F., Philippe, H. y Heidmann, T. (1999). ERV-L elements: a family of endogenous retrovirus-like elements active through the evolution of mammals. J. Virol. 73, 3301-3308.

Benveniste, R E. y Todaro, G. J. (1974). Evolution of C-type viral genes: inheritance of exogenously acquired viral genes. Nature 252, 456-459.

Bi, S., Gavrilova, O., Gong, D. W., Mason, M. M. y Reitman, M. (1997). Identification of a placental enhancer for the human leptin gene. J. Biol. Chem. 272, 30583-30588.

Blond, J. L., Beseme, F., Duret, L., Bouton, O., Bedin, F., Perron, H., Mandrand, B y MALLET, F. (1999). Molecular characterization and placental expression of HERVW, a new human endogenous retrovirus family. J. Virol. 73, 1175-1185.

Blond, J. L., Lavillette, D., Cheynet, V., Bouton, O., Oriol, G., Chapel-Fernandes, S., Mandrand, B., MALlet, F. y Cosset, F.L. (2000). An envelope glycoprotein of the human endogenous retrovirus HERV-W is expressed in the human placenta and fuses cells expressing the type D mammalian retrovirus receptor. J. Virol. 74, 3321-3329.

BOCK, M. y STOYE, J. P. (2000). Endogenous retroviruses and the human germ line. Curr. Op. Genet. Develop. 10, 651-655.

BOWEN, N. J. y MCDONALD, J.F. (1999): Genomic analysis of Caenorhabditis elegans reveals ancient families of retroviral-like elements. Genome Research 9, 924-935.

BoYD, M.T., BAX, C.M., BAX, B.E., BLOXAM, D.L. y WEISS, R.A. (1993). The human endogenous retrovirus $E R V-3$ is upregulated in differentiating placental trophoblast cells. Virology 196, 905-909.

BRosius, J. (1999a). Genomes were forged by massive bombardments with retroelements and retrosequences. Genetica 107, 209-238.

BRosiUs, J. (1999b). RNAs from all categories generate retrosequences that may be exapted as novel genes or regulatory elements. Gene 238, 115-134.

BRosiUS, J. y GOULD, S. J. (1992). On 'genomenclature': a comprehensive (and respectful) taxonomy for pseudogenes and other 'junk DNA'. Proc. Natl. Acad. Sci. USA 89, 10706-10710.

CÁceres, M., RANZ, J. M., BARBAdilla, A. Long, M. y RuIS, A. (1999). Generation of a widespread Drosophila inversion by a transposable element. Science 285, 415-418.

CAPY, P., LANGin, Y., Higuet, D. MAURER, P. y BAZIN, C. (1997). Do the integrases of LTRretrotransposons and class II element transposases have a common ancestor? Genetica $100,63-72$.

Caricasole, A., Ward-Van Oostwaard, D., Mummery, C. y Van Den Eijnden-Van RAAIJ, A. (2000a). Bone morphogenetic proteins and retinoic acid induce human endogenous retrovirus HERV-K expression in NT2D1 human embryonal carcinoma cells. Dev. Growth Differ. 42, 407-411. 


\section{Carlos Sentís}

Caricasole, A., Ward-Van OostwaArd, D.,Zeinstra, L., Van Den Eijnden-Van RaAiJ, A.y Mummery, C. (2000b). Bone morphogenetic proteins (BMPs) induce epithelial differentiation of NT2D1 human embryonal carcinoma cells. Int. J. Dev. Biol. 44, 443450.

Casau, A. E., Vaughan, J. E., Lozano, G. y Levine, A. J. (1999). Germ cell expression of an isolated human endogenous retroviral long terminal repeat of the HERV-K/HTDV family in transgenic mice. J. Virol. 73, 9976-9983.

Christensen, T., Dissing Sorensen, P., Riemann, H., Hansen, H. J., Munch, M., HAAHR, S. y MOLLER-LARSEN, A. (2000). Molecular characterization of HERV-H variants associated with multiple sclerosis. Acta Neurol. Scand. 101, 229-238.

Dangel, A. W., Mendoza, A. R., Baker, B. J., Daniel, C. M., Carroll, M. C., Wu, L. C. y YU, C. Y. (1994). The dichotomous size variation of human complement $C 4$ genes is mediated by a novel family of endogenous retroviruses, which also stablishes speciesspecific genomic patterns among Old World primates. Immunogenetics 40, 425-436.

DANIEL, J. C. y ChILTON, B. S. (1978). Virus-like particles in embryos and female reproductive tract. Devel. Mammals 3, 131-187.

Dawkins, R., Leelayuwat, C., Gaudieri, S. Tay, G., Hui, J. Cattley, S., Martínez, P. y KULSKI, J. (1999). Genomics of the major histocompatibility complex: haplotypes, duplication, retroviruses and disease. Immunol. Rev. 167, 275-304.

De Parseval, N. y Heidmann, T. (1998). Physiological knockout of the envelope gene of the single-copy ERV-3 human endogenous retrovirus in a fraction of the caucasian population. J. Virol. 72, 3442-3445.

De Parseval, N., AlkabBani, H. y Heidmann, T. (1999). The long terminal repeats of the $H E R V-H$ human endogenous retrovirus contain binding sites for transcriptional regulation by the myb protein. J. Gen. Virol. 80, 841-845.

DENNER, J. (1998). Immunosuppresion by retroviruses: implications for xenotransplantation. Ann. N.Y. Acad. Sci. 30, 862-875.

DEVOR, E. J. (2001). Use of molecular beacons to verify that the serine hidroxymethyltransferase pseudogene SHMT-ps 1 is unique to the order Primates. Genome Biology $2(2), 0006$.

DIRKSEN, E. R. y LEVY, J. A. (1977): Virus-like particles from normal individuals and patients with systemic lupus erythematosus. J. Natl. Cancer Inst. 59, 1187-1192.

Dover, G. (2000). How genomic and developmental dynamics affect evolutionary processes. Bioessays 22, 1153-1159.

GAGNEUx, P. y VARKI, A. (2001). Genetic differences between human and great apes. Mol. Phylogenet. Evol. 18, 2-13.

GONCALVES, I., DuRET, L. y MOUChIROUd, D. (2000). Nature and structure of human genes that generate retropseudogenes. Genome Res. 10, 672-678.

GRAY, Y. H. (2000). It takes two transposons to tango: transposable element-mediated chromosomal rearrangements. Trends Genet. 16, 461-468.

HÄÄHR, S. y MUNCH, M. (2000). The asociation between multiple sclerosis and infection with Epstein-Barr virus and retrovirus. J. Neurovirol. 6, 76-79.

HACIA, J. G. (2001). Genome of the apes. Trends Genet. 17, 637-645.

HAIG, D. (1992). Genomic imprinting and the theory of parent-offspring conflict. Semin. Dev. Biol. 3, 153-160.

Hara, I., IzUi, S., McConahey, P. J., Elder, J. H., Jensen, F. C. y DiXon, F. J. (1981). Induction of high serum levels of retroviral env gene products (gp70) in mice by bacterial lipopolysaccharide. Proc. Natl. Acad. Sci. USA 78, 4397-4401. 


\section{Retrovirus endógenos humanos: Significado biológico...}

HARRIS, J. R. (1998). Placental endogenous retrovirus (ERV): structural, functional, and evolutionary significance. Bioessays 20, 307-316.

Henson, M. C. y CASTRACANe, V. D. (2000). Leptin in pregnancy. Biol. Reprod. 63, 12191228.

Herniou, E., Martin, J., Miller, K., Cook, J., Wilkinson, M. y Tristem, M. (1998). Retroviral diversity and distribution in vertebrates. J. Virol. 72, 5955-5966.

Hohenadl, C., Germaier, H., Walchner, M., Hagenhofer, M., Herrmann, M., Kind, P., HeHLMANN, R., ERFLe, V. y LEIB-MOSCH, C. (1999). Transcriptional activation of endogenous retroviral sequences in human epidermal keratinocytes by UVB irradiation. J. Invest. Dermatol. 113, 587-594.

Hohenadl, C., Leib-Mosch, C., Hehlman, R. y ERfle, V. (1996). Biological significance of human endogenous retroviral sequences. J. Acquir. Immune Defic. Synd. Hum Retrovirol. 13, 268-273.

IMAMURA, M., PHILliPS, P. E. y MEllors, R. C. (1976). The ocurrence and frequency of type $C$ virus-like particles in placentas from patients with systemic lupus erythematosus and from normal subjects. Am. J. Pathol. 83, 383-394.

IsRael, S., Mendelovitz, M. y Honigman, A. (1995): Transactivation of human T-cell leukemia virus type 1 by herper simplex virus type 1. Virus Genes 9, 269-276.

JoHnson, P. M. (1993). Immunobiology of the human placental trophoblast. Exp. Clin. Immunogenet. 10, 118-122.

KAPITONOV, V. V. y JURKA, J. (1999). The long terminal repeat of an endogenous retrovirus induces alternative splicing and encodes an additional carboxy-terminal sequence in the human leptin receptor. J. Mol. Evol. 48, 248-251.

KARlsson, H., BACHMANN, S., Schroder, J., McARThur, J., TORREy, E. F. y Yolken, R. H. (2001). Retroviral RNA identified in the cerebrospinal fluids and brains of individuals with schizophrenia. Proc. Natl. Acad. Sci. USA 98, 4634-4639.

Kato, N., Shimotohno, K., Vanleeuwen, D. y Cohen, M. (1990). Human proviral mRNAs downregulated in choriocarcinoma encode a zinc finger protein related to Kruppel. Mol. Cell Biol. 10, 4401-4405.

KHAN, A. S., MULleR, J. y SEARS, J.F. (2001). Early detection of endogenous retroviruses in chemically induced mouse cells. Virus Res. 5, 39-45.

KIDWELl, M. G. y LISCH, D. (1997). Transposable elements as sources of variation in animals and plants. Proc. Natl. Acad. Sci. USA 94, 7704-7711.

Kim, A., Terzian, C., Santamaria, P., Pelisson, A., Purd'homme, N. y Bucheton, A. (1994). Retroviruses in invertebrates: the gypsy retrotransposon is apparently an infectious retrovirus of Drosophila melanogaster. Proc. Natl. Acad. Sci. USA 91, 12851289.

Kim, H. S., WadekaR, R. V., Takenaka, O., Winstanley, C., Mitsunaga, F., Kageyama, T., HYUN, B .H. y CROW, T. J. (1999). SINE-R.C2 (a Homo sapiens specific retroposon) is homologous to cDNA from postmortem brain in schizophrenia and to two loci in the Xq21.3/Yp block linked to handedness and psychosis. Am. J. Med. Genet. 88, 560-566.

KING, L. M. y Francomano, C. A. (2001). Characterization of a human gene encoding nucleosomal binding protein nsbp1. Genomics 71, 163-173.

KNosSL, M., LÖWER, R. y LÖWER, J. (1999). Expression of the human endogenous retrovirus HTDV/HERV-K is enhanced by cellular transcription factor YY1. J. Virol. 73, 1254-1261.

Kobayashi, K., NAKAHORI, Y., MryaKe, M., MATSUMURA, K., KONDO-LidA, E., NomURA, Y., Segawa, M., Yoshioka, M., Saito, K., Osawa, M., Hamano, K., Sakakihara, Y., No- 


\section{Carlos Sentís}

Naka, I., Nakagome, Y., Kanazawa, I., NakamuRa, Y., Tokunaga, K. y Toda, T. (1998): An ancient retrotransposal insertion causes Fukuyama-type congenital muscular distrophy. Nature 394, 388-392.

Koralnik, I. J., Boeri, E., Saxinger, W. C., Monico, A. L., Fullen, J., Gessain, A., Guo, H. G., Markham, P., Kalyaranaman, V. et al. (1994). Phylogenetic associations of human and simian T-cell leukemia/lymphotropic virus type I strains. Evidence for interspecies transmission. J. Virol. 68, 2698-2707.

KowAlski, P. E., FreEmAN, J. D., Nelson, D. T. y MAGER, D. L. (1997). Genomic structure and evolution of a novel gene (PLA2L) with duplicated phospholipase A2-like domains. Genomics 39, 38-46.

Kubo, Y., Kakimi, K., Higo, K., KOBayashi, H., OHNo, T., Iwama, Y., KuRIBAyashi, K., HIAI, H., ADACHI, A. y IsHimoto, A. (1996). Possible origin of murine AIDS (MAIDS) virus: conversion of an endogenous retroviral p12gag sequence to a MAIDS-inducing sequence by framshift mutations. J. Virol. 70, 6405-6409.

Kulski, J. K., GAUDIERI, S., INOKo, H. y DAwKINS, R. L. (1999). Comparison between two human endogenous retrovirus (HERV)-rich regions within the major histocompatibility complex. J. Mol. Evol. 48, 657-683.

LABRADOR, M., FARRE, M., UtZET, F. y FONTDEVILA, A. (1999). Interspecific hybridization increases transposition rates of Osvaldo. Mol. Biol. Evol. 16, 931-937.

LARSSON, E., ANDERSSON, A. C. y NILSSON, B. O. (1994). Expression of an endogenous retrovirus (ERV3/HERV-R) in human reproductive and embryonic tissues: evidence for a function for envelope gene products. Upss. J. Med. Sci. 99, 113-120.

LATEN, H. M., MAJUMdAR, A. y GAUCHER, E. A. (1998). SIRE-1, a copia/Ty1-like retroelement from soybean, encodes a retroviral envelope-like protein. Proc. Natl. Acad. Sci. USA 95, 6897-6902.

Lavrentieva, I., Khil, P., Vinogradova, T., AkHmedov, A., LAPUK, A., SHAKHova, O., LEBedeV, Y., MonAStyrkaya, G. y Sverdlov, E. D. (1998). Subfamilies and nearestneighbour dendrogram for the LTRs of human endogenous retroviruses HERV-K mapped on human chromosome 19: physical neighbourhood does not correlate with identity level. Hum. Genet. 102, 107-116.

Leblanc, P., Desset, S., Giorgi, F., Taddei, A. R., Fausto, A. M., Mazzini, M., DastuGUE, B. y VAURY, C. (2000). Life cycle of an endogenous retrovirus, ZAM, in Drosophila melanogaster. J. Virol. 74, 10658-10669.

LI, W H., GU, Z., WANG, H. y NEKRUTENKO, A. (2001). Evolutionary analysis of the human genome. Nature 409, 847-849.

LIN, L., XU, B. y Rote, N. S. (1999). Expression of endogenous retrovirus ERV-3 induces differentiation in BeWo, a choriocarcinoma model of human placental trophoblast. Placenta 20, 109-118.

LINDESKOG, M. y BLOMBERG, J. (1997). Spliced human endogenous retroviral HERV-H env transcripts in T-cell leukaemia cell lines and normal leukocytes: alternative splicing pattern of HERV-H transcripts. J. Gen. Virol. 78, 2575-2585.

Lindeskog, M., Medstrand, P., Cunningham, A. A. y Blomberg, J. (1998). Coamplification and dispersion of adjacent human endogenous retroviral HERV-H y HERV-E elements; presence of spliced hybrid transcripts in normal leukocytes. J. Virol. 25, 219-229.

LOKE, Y. W. y KING, A. (1997). Immunology of human placental implantation: clinical implications of our current understanding. Mol. Med. Today 3, 153-159.

LÖWER, R. (1999). The pathogenic potential of endogenous retroviruses: facts and fantasies. Trends Microbiol.7, 350-356. 
LÖWER, R., LÖWER, J. y KURTH, R. (1996). The viruses in all of us: characteristics and biological significance of human endogenous retrovirus sequences. Proc. Natl. Acad. Sci. USA 93, 5177-5184.

Mager, D. L., Hunter, D. G., Schertzer, M. y Freeman, J. D. (1999). Endogenous retroviruses provide the primary polyadenylation signal for two new human genes (HHLA2 and HHLA3). Genomics 59, 255-263.

MANG, R., MAAS, J., Chen, X., GOUdSMit, J. y VAN DER KUYL, A. C. (2001). Identification of a novel type $C$ porcine endogenous retrovirus: evidence that copy number of endogenous retroviruses increases during host inbreeding. J. Gen. Virol. 82, 1829-1834.

MANG, R., MAAS, VAN DeR KuYL, A. C. y Goudsmit, J. (2000). Papio cynocephalus endogenous retrovirus among old world monkeys: evidence for coevolution and ancient cross-species transmissions. J. Virol. 74, 1578-1586.

MARTin, J., Herniou, E., COOK, J., O‘Neill, R. W. y TRISTEM, M. (1999). Interclass transmission and phyletic host tracking in murine leukemia virus-related retroviruses. J. Virol. 73, 2442-2449.

Martin, J., Herniou, E., CoOK, J., WaUgh O'Neill, R. y Tristem, M. (1997). Human endogenous retrovirus type I-related viruses have an apparently widespread distribution within vertebrates. J. Virol. 71, 437-443.

MARTIN, M. A., BRYAN, T., RASHEED, S. y KHAN, A. S. (1981). Identification and cloning of endogenous retroviral sequences present in human DNA. Proc. Natl. Acad. Sci. USA $78,4892-4896$.

MCCLINTOCK, B. (1984). The significance of responses of the genome to challenge. Science 226, 792-801.

Medstrand, P., Mager, .L., Yin, H., Dietrich, U. y Blomberg, J. (1997). Structure and genomic organization of a novel human endogenous retrovirus family: HERV-K (HML-6). J. Gen. Virol. 78, 1731-1744.

Medstrand, P y MAGER, D. L. (1998). Human-specific integrations of the HERV-K endogenous retrovirus family. J. Virol. 72, 9782-9787.

MEdSTRAND, P., LANDRY, J. R. y MAGER, D. L. (2001). Long terminal repeats are used as alternative promoters for the endothelin $B$ receptor and apolipoprotein $C$-I genes in humans. J. Biol. Chem. 276, 1896-1903.

Mi, S., Lee, X., Li, X., Veldman, G. M., Finnerty, H., Racie, L., Lavallie, E., Tang, X.Y., EdouARD, P., Howes, S., KeITH, J. C. y MCCOY, J. M. (2000). Syncytin is a captive retroviral envelope protein involved in human placental morphogenesis. Nature 403, 785-789.

Mikkelsen, J. G. y PEDERSEn, F. S. (2000). Genetic reassortment and patch repair by recombination in retroviruses. J. Biomed. Sci. 7, 77-99.

NEKRUTENKo, A. y LI, W. H. (2001). Transposable elements are found in a large number of human protein-coding genes. Trends in Genetics 17, 619-621.

NELSON, J., LEONG, J. A. y LeVY, J. A. (1978). Normal human placentas contain RNA-directed DNA polymerase activity like that in viruses. Proc. Natl. Acad. Sci. USA 75, 6263-6267.

Nilsson, B. O., Kattstrom, P. O., Sundstrom, P., Jaquemin, P. y Larsson, E. (1992). Human oocytes express murine retroviral equvalents. Virus genes 6, 221-227.

OBER, C. (1992). The maternal-fetal relationship in human pregnancy: an immunogenetic perspective. Exp. Clin. Immunogenet. 9, 1-14.

PANTAZIDIS, A., LABRADOR, M. y FonTdEvila, A. (1999). The retrotransposon osvaldo from Drosophila buzzati displays all structural features of a functional retrovirus. Mol. Biol. Evol. 16, 909-921. 


\section{Carlos Sentís}

PATIENCE, C., TAKeUChi, Y. y Weiss, R. A. (1997a). Infection of human cells by an endogenous retrovirus of pigs. Nat. Med. 3, 282-286.

Patience, C., Wilkinson, D. A. y WEiss, R. (1997b). Our retroviral heritage. Trends Genet. 13, 116-120.

Perron, H., Perin, J. P., Rieger, F. y Alliel, P. M. (2000). Particle-associated retroviral RNA and tandem RGH/HERV-W copies on human chromosome 7q: possible components of a 'chain-reaction' triggered by infectious agents in multipli sclerosis? J. Neurovirol. 2, 67-75.

Peterson-Burch, B. D., Wright, D. A., Laten, H. M. y Voytas, D. F. (2000). Retroviruses in plants? Trends Genet. 16, 151-152.

Pouteau, S., Huttner, E., Grandbastien, M. A. y Caboche, M. (1991). Specific expression of the tobacco Tnt1 retrotransposon in protoplasts. EMBO J. 10, 1911-1918.

Puech, A., Duppressoir, A., Loireau, M. P., Mattei, M. G. y Heidmann, T. (1997). Characterization of two age-induced intracisternal A-particle-related transcripts in the mouse liver. Transcriptional read-through into an open reading frame with similarities to the yeast ccr4 transcription factor. J. Biol. Chem. 272, 5995-6003.

Reaves, P. Y., Gelband, C. H., Wang, H., Yang, H., Lu, D., BereceK, K. H., Katovich, M. J. y RAIZADA, M. (1999): Permanent cardiovascular protection from hypertension by the $A T(1)$ receptor antisense gene therapy in hypertensive rat offspring. Circulation Research 12, 44.50.

Samuelson, L. C., Wiebauer, K., Snow, C. M. y Meisler, M. H. (1990). Retroviral and pseudogene insertion sites reveal the lineage of human salivary and pancreatic amylase genes from a single gene during primate evolution. Mol. Cell Biol. 10, 2513-2520.

SCHNEIDER, P. M., WiTEL-SCHLOMP, K., RITTNER, C. y ZHANG, L. (2001). The endogenous retroviral insertion in the human complement $C 4$ gene modulates the expression of homologous genes by antisense inhibition. Immunogenetics 53, 1-9.

Schon, U., Seifarth, W., Baust, C., Hohenadl, C., Erfle, V. y Leib-Mosch, C. (2001). Cell type-specific expression and promoter activity of human endogenous retroviral long terminal repeats. Virology 279, 280-291.

Schulte, A. M., Lai, S., Kurtz, A., Czubayko, F., Riegel, A. T. y Wellstein, A. (1996). Human trophoblast and choriocarcinoma expression of the growth factor pleiotrophin attributable to germ line insertion of an endogenous retrovirus. Proc. Natl. Acad. Sci. USA 93, 14759-14764.

Shen, L., Wu, L. C., Sanlioglu, S., Chen, R., Mendoza, A. R., Dangel, A. W., Carroll, M. C., ZIPF, W. B. y YU, C. Y. (1994). Structure and genetics of the partially duplicated gene RP located immediately upstream of the complement $C 4 A$ and the $C 4 B$ genes in the HLA class III region. Molecular cloning, exon-intron structure, composite retroposon, and breakpoint of gene duplication. J. Biol. Chem. 18, 8466-8476.

Sinkovics, J. G. (2001). The place of viruses in the "tree of life». Acta Microbiol. Immunol. Hung. 48, 115-127.

Sionov, R. V., YAGEL, S., HAR-NIR, R. y GAllily, R. (1993). Trophoblasts protect the inner cell mass from macrophage destruction. Biol. Reprod. 49. 588-595.

SMIT, A. F. A. (1999). Interspersed repeats and other mementos of transposable elements in mammalian genomes. Curr. Opin. Genet. Develop. 9, 657-663.

Stevens, R. W., Baltch, A. L., Smith, R. P., McCreedy, B. J., Michelsen, P. B., Bopp, L. H. y URNovitz, H. B. (1999). Antibody to human endogenous retrovirus peptide in urine of human immunodeficiency virus type 1-positive patients. Clin. Diag. Lab. Immunol. 6, 783-786. 
Strazzullo, M., Parisi, T., Di Cristofano, A., Rocchi, M. y La Mantia, G. (1998). Characterization and genomic mapping of chimeric ERV9 endogenous retroviruses-host gene transcripts. Gene 206, 77-83.

STROMBERG, K. y BENVENISTE, R. (1983). Efficient isolation of endogenous rhesus retrovirus from trophoblast. Virology 128, 518-523.

Sugimoto, J., MatsuURa, N., Kinjo, Y., TAKasu, N., Oda, T. y Jinno, Y. (2001). Transcriptionally active HERV-K genes: identification, isolation and chromosomal mapping. Genomics 72, 137-144.

Svensson, A. C., Raudsepp, T., Larsson, C., Di Cristofano, A., Chowdhary, B., LamanTIA, G., RASK, L. y ANDERSSON, G. (2001). Chromosomal distribution, localization and expression of the human endogenous retrovirus ERV9. Cytogenet. Cell Genet. 92, 8996.

TANDA, S., Mullor, J. L. y CoRCES, V. G. (1994). The Drosophila tom retrotransposon en codes an envelope protein. Mol. Cell Biol. 14, 5392-5401.

Tassabehji, M., Strachan, T., Andersson, M., Campbell, R. D., Collier, S. y LaKo, M. (1994). Identification of a novel family of human endogenous retroviruses and characterization of one family member, $\mathrm{HERV}-\mathrm{K}(\mathrm{C} 4)$, located in the complement $\mathrm{C} 4 \mathrm{clus}$ ter. Nucl. Acid Res. 11, 5211-5217.

TCHenio, T. y Heidmann, T. (1991). Defective retroviruses can disperse in the human genome by intracellular transposition. J. Virol. 65, 2113-2118.

The GENOME SEQUENCING CONSORTIUM (2001). Initial sequencing and analysis of the human genome. Nature 409, 860-921.

Ting, C. N., Rosenberg, M. P., Snow, C. M., SAmuelson, L. C. y Meisler, M. H. (1992). Endogenous retroviral sequences are required for tissue-specific expression of a human salivary amylase gene. Genes Dev. 6, 1457-1465.

TRAVIS, J. (1992). Possible evolutionary role explored for «jumping genes». Science 257, 884-885

TRISTEM, M. (2000). Identification and characterization of novel human endogenous retrovirus families by phylogenetic screening of the human genome mapping project database. J. Virol. 74, 3715-3730.

Turner, G., Barbulescu, M., Su, M., Jensen-Seaman, M. I., Kidd, K. K. y LenZ, J. (2001). Insertional polymorphisms of full-length endogenous retroviruses in humans. Curr. Biol. 11, 1531-1531.

Ueno, H., Imamura, M. y KIKUCHI, H. (1983). Frequency and antigenicity of type $C$ retrovirus-like particles in human placentas. Virchows Arch. A. Pathol. Anat. Histopathol. 400, 31-41.

Villareal, L. P. (1997). On viruses, sex and motherhood. J. Virol. 71, 859-865.

VILlaREAL, L. P. y DEFILIPPIS, V. R. (2000). A hypothesis for DNA viruses as the origin of eukaryotic replication proteins. J. Virol. 74, 7079-7084.

Voisset, C., Bouton, O., Bedin, F., Duret, L., Mandrand, B., Mallet, F. y Paranhos-BaCCALA, G. (2000). Chromosomal distribution and coding capacity of the human endogenous retrovirus HERV-W family. AIDS Res. Hum. Retroviruses. 16, 731-740.

Wei, W., Gilbert, N., OoI, S. L., LaWler, J. F., OstertaG, E. M., KaZAZian, H. H., Boeke, J. D. y MORAN, J. V. (2001). Human L1 retrotransposition: cis preference versus trans complementation. Mol. Cell Biol. 21, 1429-1439.

Weiss, R. A. (2000). Ancient and modern retroviruses. Acta Microbiol. Immunol. Hung. 47, 403-410.

WESSLER, S. R. (1996). Turned on by stress. Plant retrotransposons. Curr. Biol. 6, 959-961. 


\section{Carlos Sentís}

166

WRAY, G. A. (1999). Evolutionary dissociations between homologous genes and homologous structures. Novartis Found. Symp. 222, 189-203.

Wray, G. A. y ABouheif, E. (1998). When is homology not homology? Curr. Opin. Genet. Develop. 8, 675-680.

WRIGHT, D. A. y VOYTAS, D. F. (1998). Potential retroviruses in plants: tat I is related to a group of Arabidopsis thaliana Ty3/gypsy retrotransposons that encode envelope-like proteins. Genetics 149, 703-715.

Yang, J., Bogerd, H. P., Peng, S., Wiegand, H., Truant, R. y Cullen, B .R. (1999). An ancient family of human endogenous retroviruses encodes a functional homolog of the HIV-1 Rev protein. Proc. Natl. Acad. Sci. USA 96, 13404-13408.

ZHANG, J. y MA, Y. (2001): Evidence for retroviral intramolecular recombinations. J. of Virology $75,6348-6358$.

ZUCKERKANDL, E. y HENNIG, W. (1995). Tracking heterochromatin. Chromosoma 104, 7583. 